\title{
IMPLEMENTASI R-SHINY UNTUK ANALISIS BIPLOT KOMPONEN UTAMA (Studi Kasus: Penggunaan Alat Kontrasepsi pada Peserta Aktif KB di Provinsi Jawa Tengah Tahun 2019)
}

\author{
Andreanto $^{1}$, Hasbi Yasin ${ }^{2}$, Agus Rusgiyono ${ }^{3}$ \\ 1,2,3 Departemen Statistika, Fakultas Sains dan Matematika, Universitas Diponegoro \\ e-mail: aanto3008@gmail.com
}

\begin{abstract}
The population problem is a fairly complex and complicated problem. Therefore, Indonesia seeks to control the birth rate with the Family Planning program. The implementation of this program can be evaluated through statistical data. The statistical analysis used is biplot principal component analysis to see the relationship between districts/cities in choosing the contraceptive device/method used, the variance of each contraceptive device/method, the correlation between contraceptive devices/methods, and the superiority value of the contraceptive device/method in the population. each district/city. The problem with performing the analysis is the limitations of easy-to-use open source software. As with R, users must understand writing code to perform data analysis. Therefore, to perform a biplot analysis of the principal components, an RShiny application has been created using RStudio. The R-Shiny that has been made has many advantages, including complete results which include data display, data transformation, SVD matrix, to graphs along with plot graph interpretation. The results of the principal component biplot analysis using R-Shiny with $\alpha=1$ have the advantage of a good principal component biplot, which is $95.63 \%$. This shows that the biplot interpretation of the main components produced can be explained well the relationship between the district/city and the contraceptive methods/devices used.
\end{abstract}

Keywords : Biplot, Principal Component, R-Shiny, Application, Family Planning

\section{PENDAHULUAN}

Jawa Tengah merupakan salah satu provinsi di Indonesia yang memiliki jumlah penduduk terbanyak, dengan jumlah penduduk di tahun 2019 mencapai 34,55 juta jiwa atau sekitar 12,28\% dari total penduduk di Indonesia. Dalam rangka menekan pertumbuhan penduduk serta upaya untuk meningkatkan kualitas sumber daya manusia, maka salah satu langkah jitu yang dilakukan pemerintah adalah dengan mengadakan program Keluarga Berencana $(\mathrm{KB})$.

Terdapat beberapa jenis alat kontrasepsi yang digunakan oleh pasangan keluarga berencana. Diantaranya adalah IUD, MOW, MOP, Kondom, Implant, Suntikan, dan Pil. Untuk melihat hasil program Keluarga Berencana (KB), ilmu statistik berperan penting dalam menyampaikan informasi tentang data peserta aktif program KB dan alat kontrasepsi yang digunakan.

Salah satu metode yang mampu untuk mendefinisikan data multivariat ke dalam bentuk grafik plot dua dimensi adalah analisis biplot komponen utama. Menurut Mattjik dan Sumertajaya (2011) dalam Sartono, dkk (2003), biplot adalah salah satu upaya menggambarkan data-data yang ada pada tabel ringkasan dalam grafik berdimensi dua. Informasi yang diberikan oleh biplot mencakup objek dan peubah dalam satu gambar. Empat hal penting yang bisa didapatkan dari tampilan biplot adalah kemiripan antar objek yang diamati, keragaman variabel, korelasi antar variabel, dan nilai variabel dari suatu objek. 
Penelitian ini menggunakan Open Source Software Rstudio dengan package R-Shiny. Menurut Tirta (2015), R-Shiny merupakan package dalam $\mathrm{R}$ yang mampu membuat tampilan web interaktif. Hasil luaran dari R-Shiny akan memberikan tampilan yang ramah untuk digunakan pengguna melakukan pekerjaan, seperti analisis statistik. Implementasi RShiny pada penelitian ini akan memberikan kemudahan pada seseorang yang kurang mengerti dalam hal pemrograman namun ingin melakukan analisis biplot komponen utama terutama pada kasus jumlah pasangan usia subur yang merupakan peserta aktif KB per kabupaten/kota berdasarkan alat kontrasepsi yang digunakan.

\section{TINJAUAN PUSTAKA \\ 2.1. Keluarga Berencana}

Menurut Undang-Undang Republik Indonesia No. 52 Tahun 2009 Tentang Perkembangan Kependudukan dan Pembangunan Keluarga, bahwa Keluarga Berencana adalah upaya mengatur kelahiran anak, jarak dan usia ideal melahirkan, mengatur kehamilan, melalui promosi, perlindungan, dan bantuan sesuai dengan hak reproduksi untuk mewujudkan keluarga yang berkualitas. Program ini merupakan program berskala nasional yang bertujuan untuk menekan angka kelahiran serta mengendalikan pertumbuhan penduduk melalui pengaturan kehamilan. Hal ini untuk membantu pasangan suami istri untuk melahirkan pada usia yang ideal, memiliki jumlah anak, dan mengatur jarak kelahiran anak yang ideal dengan menggunakan cara, alat, dan obat kontrasepsi.

\subsection{Nilai Eigen dan Vektor Eigen}

Diberikan sebuah matriks $\mathbf{Y}$ berukuran $n \times n$, dan vektor $\boldsymbol{x} \neq 0$ pada $\mathbb{R} n$, maka disebut vektor eigen dari $\mathbf{Y}$ jika $\mathbf{Y} \boldsymbol{x}$ adalah sebuah kelipatan skalar dari $\boldsymbol{x}$, atau :

$$
\mathbf{Y} \boldsymbol{x}=\lambda \boldsymbol{x}
$$

Untuk skalar sebarang $\lambda$, dimana skalar $\lambda$ adalah nilai eigen dari matriks $\mathbf{Y}$, dan $\boldsymbol{x}$ adalah vektor eigen dari matriks $\mathbf{Y}$. Untuk mendapatkan nilai eigen dan vektor eigen dari matriks $\mathbf{Y}$, persamaan (1) dapat ditulis kembali sehingga menjadi :

$$
\begin{gathered}
\mathrm{Y} \boldsymbol{x}=\lambda \mathrm{I} \boldsymbol{x} \\
\mathrm{Y} \boldsymbol{x}-\lambda \mathrm{I} \boldsymbol{x}=\mathbf{0} \\
(\mathrm{Y}-\lambda \mathrm{I}) \boldsymbol{x}=\mathbf{0}
\end{gathered}
$$

Berdasarkan persamaan (2), jika $\operatorname{det}(\mathbf{Y}-\boldsymbol{\lambda I}) \neq \mathbf{0}$ atau $(\mathbf{Y}-\boldsymbol{\lambda} \mathbf{I})$ memiliki invers, maka $\boldsymbol{x}=\mathbf{0}$. Oleh karena itu, agar $\boldsymbol{\lambda}$ memiliki solusi tak nol, maka persamaan tersebut jika dan hanya jika $\operatorname{det}(\mathrm{Y}-\lambda \mathrm{I})=0$. Oleh karena itu, terdapat $\mathrm{n}$ nilai eigen, yaitu $\lambda_{1}, \lambda_{2}, \ldots, \lambda_{\mathrm{n}}$ untuk matriks Y. Untuk setiap nilai eigen $\lambda_{\mathrm{j}}$, ada vektor eigen $\mathrm{x}_{\mathrm{j}}$, bersesuaian $\left(\lambda_{\mathrm{j}}, \mathrm{x}_{\mathrm{j}}\right)$ yang diberikan oleh persamaan (2).

\subsection{Biplot Principal Component Analysis}

Menurut Rifkhatussa'diyah (2014), analisis biplot komponen utama atau juga disebut dengan biplot klasik adalah salah satu teknik statistika deskriptif berupa representasi grafik yang dapat menyajikan secara simultan $\mathrm{n}$ buah objek dan $\mathrm{p}$ buah variabel dalam satu grafik berdimensi dua. Kemudian menurut Sartono (2003) dalam Mattjik \& Sumertajaya (2011), hal penting yang bisa didapatkan dari tampilan biplot adalah kedekatan antar objek, keragaman variabel, korelasi antar variabel, dan nilai variabel pada suatu objek.

Langkah-langkah dalam analisis biplot komponen utama adalah sebagai berikut :

1. Membuat matriks data yang telah dikoreksi terhadap rata-rata

2. Menghitung nilai eigen dan vektor eigen 
3. Pendekatan melalui Singular Value Decomposition (SVD)

4. Identifikasi persentase keragaman data

5. Membuat pemetaan biplot komponen utama dan interpretasi plot.

\subsection{Singular Value Decomposition (SVD)}

Diberikan sebuah matriks $\mathrm{Y}$ berukuran $\mathrm{n} \times \mathrm{p}$ yang berisi $\mathrm{n}$ objek penelitian dan $\mathrm{p}$ variabel dapat difaktorkan dalam bentuk :

$$
\mathbf{Y}_{(\mathbf{n x p})}=\mathbf{U}_{(\mathbf{n x r})} \mathbf{L}_{(\mathbf{r x r})} \mathbf{A}^{\mathbf{T}}(\mathbf{r x p})
$$

Matriks $\mathbf{U}$ merupakan matriks orthnormal, dimana uk merupakan kolom matriks $U$ yang nilai-nilainya diperoleh dari $\mathbf{u}_{\mathrm{k}}=\frac{1}{\sqrt{\lambda_{\mathrm{k}}}}$ Yak . Matriks A merupakan matriks orthonormal, $\mathbf{a}_{\mathrm{k}}$ dengan $\mathrm{k}=1,2, \ldots, \mathrm{r}$ merupakan kolom matriks A yang elemen-elemennya merupakan vektor eigen dari $\mathbf{Y}^{\mathrm{T}} \mathbf{Y}$ dan nilai eigen $\lambda_{\mathrm{k}}$. Kemudian matriks $\mathbf{L}$ merupakan matriks diagonal, dengan unsur diagonalnya merupakan akar kuadrat dari nilai eigen $\mathbf{Y}^{\mathrm{T}} \mathbf{Y}$, yaitu $\mathbf{L}=\operatorname{diag}\left(\sqrt{\lambda_{1}}, \sqrt{\lambda_{2}}\right.$, $\ldots, \sqrt{\lambda_{\mathrm{r}}}$ ) dengan $\sqrt{\lambda_{1}} \geq \sqrt{\lambda_{2}} \geq \ldots \geq \sqrt{\lambda_{\mathrm{r}}}$.

Selanjutnya menurut Mattjik \& Sumertajaya (2011), didefinisikan $\mathbf{L}^{\alpha}$, dengan $0 \leq \alpha \leq 1$ dan definisi ini berlaku juga untuk matriks diagonal $\mathbf{L}^{1-\alpha}$ dengan $0 \leq \alpha \leq 1$. Misalkan $\mathbf{G}=$ $\mathbf{U L}^{\boldsymbol{\alpha}}$ dan $\mathbf{H}^{\mathbf{T}}=\mathbf{L}^{1-\alpha} \mathbf{A}^{\mathbf{T}}$ dengan $0 \leq \alpha \leq 1$, maka persamaan (3) menjadi :

$$
\mathbf{Y}=\mathbf{G} \mathbf{H}^{\mathbf{T}}
$$

Dari persamaan (4) maka unsur dari matriks $\mathbf{Y}$ dapat ditulis ke dalam persamaan :

$$
\mathrm{y}_{\mathrm{ij}}=\mathbf{g}_{\mathrm{i}}^{\mathrm{t}} \mathbf{h j}, \quad \mathrm{i}=1,2, \ldots, \mathrm{n} \& \mathrm{j}=1,2, \ldots, \mathrm{p}
$$

$\mathbf{g}_{\mathrm{i}}^{\mathrm{t}}$ dan $\mathbf{h}_{\mathrm{j}}$ memiliki $\mathrm{r}$ elemen, dan jika $\mathbf{Y}$ memiliki rank 2, maka vektor baris $\mathbf{g}_{\mathrm{i}}$ dan $\mathbf{h}_{\mathrm{j}}$ dapat digambarkan ke dalam ruang berdimensi dua. Menurut Mattjik \& Sumertajaya (2011), jika ada m elemen unsur yang dipertahankan, persamaan di atas dapat didekati dalam persamaan di bawah ini:

$$
{ }_{\mathrm{m}} \tilde{y}_{\mathrm{ij}}=\boldsymbol{g}_{i}^{* \mathrm{t}} \boldsymbol{h}_{j}^{*}
$$

Dengan $\boldsymbol{g}_{i}^{*}$ dan $\boldsymbol{h}_{j}^{*}$ masing-masing berisi m elemen unsur vektor dari dari $\mathbf{g}_{\mathbf{i}}$ dan $\mathbf{h}_{\mathbf{j}}$. Jika $\mathrm{m}=2$, maka inilah yang disebut dengan biplot, sehingga persamaan (6) menjadi:

$$
{ }_{2} \tilde{y}_{\mathrm{ij}}=\boldsymbol{g}_{i}^{*} \boldsymbol{h}_{j}^{*}
$$

Dengan ${ }_{2} \tilde{y}_{\mathrm{ij}}$ merupakan unsur pendekatan matriks $\mathbf{Y}$. Kemudian diperoleh matriks $\mathbf{G}$ dan $\mathbf{H}$ berdimensi dua dari pendekatan matriks $\mathbf{Y}$ sebagai berikut :

$\mathbf{G}=\left[\begin{array}{cc}g_{11} & g_{12} \\ \vdots & \vdots \\ g_{i 1} & g_{i 2} \\ \vdots & \vdots \\ g_{n 1} & g_{n 2}\end{array}\right]$ dan $\mathbf{H}=\left[\begin{array}{cc}h_{11} & h_{12} \\ \vdots & \vdots \\ h_{j 1} & h_{j 2} \\ \vdots & \vdots \\ h_{p 1} & h_{p 2}\end{array}\right]$

Matriks $\mathbf{G}$ adalah titik-titik koordinat dua dimensi dari n objek dan matriks $\mathbf{H}$ adalah titiktitik koordinat dua dimensi dari $\mathrm{p}$ variabel.

Jika $\alpha=1$, maka $\mathbf{G}=\mathbf{U L}$ dan $\mathbf{H}=\mathbf{A}$, sehingga : 


$$
\begin{aligned}
\mathbf{Y} \mathbf{Y}^{\mathbf{T}} & =\left(\mathbf{G} \mathbf{H}^{\mathbf{T}}\right)\left(\mathbf{G} H^{\mathbf{T}}\right)^{\mathbf{T}} \\
& =\mathbf{G H}^{\mathbf{T}} \mathbf{H} \mathbf{G}^{\mathbf{T}} \\
& =\mathbf{G A}^{\mathbf{T}} \mathbf{A} \mathbf{G}^{\mathbf{T}} \\
& =\mathbf{G G}^{\mathbf{T}}
\end{aligned}
$$

Pada keadaan ini, jarak Euclid antara $\mathbf{g}_{\mathrm{i}}$ dan $\mathbf{g}_{\mathrm{j}}$ akan sama dengan jarak Euclid antara objek pengamatan $\mathbf{x}_{\mathrm{i}}$ dan $\mathbf{x}_{\mathbf{j}}$, keadaan ini dikarenakan $\left(\mathbf{y}_{\mathrm{i}}-\mathbf{y}_{\mathrm{j}}\right)^{\mathrm{T}}\left(\mathbf{y}_{\mathrm{i}}-\mathbf{y}_{\mathrm{j}}\right)=\left(\mathbf{g}_{\mathrm{i}}-\mathbf{g}_{\mathrm{j}}\right)^{\mathrm{T}}\left(\mathbf{g}_{\mathrm{i}}-\mathbf{g}_{\mathrm{j}}\right)$.

Ukuran kebaikan matriks $\mathbf{Y}$ dengan biplot dapat dihitung dalam rumus :

$$
\rho^{2}=\frac{\lambda_{1}+\lambda_{2}}{\sum_{k=1}^{r} \lambda_{k}}
$$

dengan $\lambda_{1}$ merupakan nilai eigen terbesar pertama, $\lambda_{2}$ merupakan nilai eigen terbesar kedua, dan $\lambda_{\mathrm{k}}$ merupakan nilai eigen terbesar ke-k untuk $\mathrm{k}=1,2, \ldots$, r. Jika nilai $\rho^{2}$ mendekati angka 1, maka biplot memberikan penyajian yang semakin baik mengenai informasi data yang sebenarnya (Mattjik \& Sumertajaya, 2011).

\subsection{R-Shiny}

R-Shiny merupakan package dari perangkat lunak pemrograman R-Studio yang memiliki fungsi sebagai alat untuk membuat interface maupun web interaktif. R-Studio sendiri merupakan perangkat lunak open-source pengembangan dari $\mathrm{R}$ untuk komputasi statistika yang memiliki tampilan lebih user-friendly. Menurut Tirta (2014), komponen program Shiny dibedakan menjadi dua kelompok besar yaitu server dan user interface (ui).

\subsubsection{Server}

Server merupakan bagian otak dari sebuah program yang berfungsi melakukan simulasi analisis data yang selanjutnya dikirim ke bagian output. Menurut Tirta (2015), dokumen file server terdiri atas dua bagian utama yaitu preambul dan server shiny yang disimpan dalam file server.R. Bagian preambul ini berisi beberapa perintah mengaktifkan library terkait, mengaktifkan data yang dibutuhkan, membangkitkan data simulasi, dan mengaktifkan fungsi-fungsi yang bersifat global.

\subsubsection{User Interface (UI)}

User Interface (UI) digunakan untuk membuat tampilan dari aplikasi atau GUI (Graphical User Interface). Pada bagian ini, kode atau syntax ditulis dan disimpan dalam file ui.R. Menurut Tirta (2015), komponen inti file ui.R yaitu setiap menu utama (navbarMenu) masing-masing akan memiliki submenu (tabPanel), kontrol input (sidebarPanel) dan tampilan output tersendiri (mainPanel).

Berikut adalah struktur umum dari komponen pemrograman menggunakan R-Shiny:

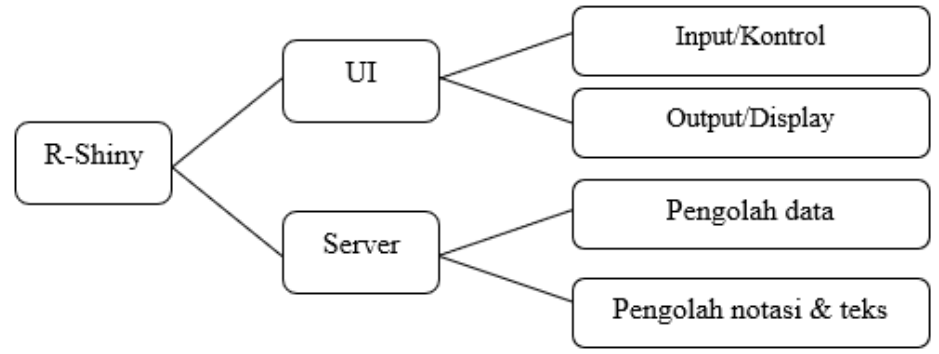

Gambar 1. Struktur Komponen R-Shiny 


\section{METODE PENELITIAN}

Data yang digunakan dalam penelitian ini merupakan data sekunder yang diambil dari Badan Pusat Statistik Provinsi Jawa Tengah, dalam bukunya yang berjudul "Provinsi Jawa Tengah Dalam Angka 2020". Data yang diambil adalah data jumlah pasangan usia subur dan peserta KB aktif menurut kabupaten/kota di Provinsi Jawa Tengah tahun 2019. Data tersebut berisi jumlah peserta menurut masing-masing Kabupaten/Kota (35 Kabupaten/Kota) dan terdapat 7 variabel alat/metode kontrasepsi. Variabel dalam penelitian ini antara lain IUD, MOW (Metode Operasi Wanita), MOP (Metode Operasi Pria), Kondom, Implant, Suntikan, dan Pil. Berikut adalah Langkah-langkah pengolahan data dalam penelitian ini :

1) Membuat matriks $\mathbf{M}$ yang telah ditransformasi terhadap rata-rata, dengan matriks asal Y berukuruan $n x p$ ( $n=35$ kabupaten/kota di Provinsi, $\mathrm{p}=7$ variabel)

2) Membuat desain tata letak interface R-Shiny, yaitu ui.R

3) Membuat program server.R pada interface R-Shiny.

4) Membentuk matriks $\mathbf{L}, \mathbf{A}$, dan $\mathbf{U}$ melalui SVD (Singular Decomposition Value).

5) Membuat matriks $\mathbf{G}=\mathbf{U} \mathbf{L}^{\boldsymbol{\alpha}}$ dan $\mathbf{H}=\mathbf{L}^{\mathbf{1 - \alpha}} \mathbf{A}$ dengan $\alpha=1$.

6) Membuat Grafik koordinat $Z$ dengan mengambil dua kolom pertama dari masingmasing matriks $\mathbf{G}$ dan $\mathbf{H}$.

7) Menghitung kesesuaian biplot dan menjelaskan keragaman data dengan menggunakan rumus $\rho^{2}=\frac{\lambda_{1}+\lambda_{2}}{\sum_{k=1}^{r} \lambda_{k}}$

8) Interpretasi biplot komponen utama.

\section{HASIL DAN PEMBAHASAN}

\subsection{Perancangan Analisis Biplot Komponen Utama}

Tahapan perancangan analisis biplot komponen utama adalah sebagai berikut :

1. Koreksi data terhadap rata-rata

Data awal $m_{i j}, \mathrm{i}=1,2,3, \ldots, \mathrm{n}$ dan $\mathrm{j}=1,2,3, \ldots, \mathrm{p}$ ditransformasi menjadi $y_{i j}=m_{i j}-\bar{m}_{. j}$. Transformasi data terhadap rata-rata dilakukan secara otomatis oleh aplikasi R-Shiny yang akan dibuat.

2. Mencari SVD dari matriks $\mathbf{Y}$

3. Memasukkan nilai $\alpha=1$ untuk mendefinisikan matriks $\mathbf{G}$ dan $\mathbf{H}$

Tahapan selanjutnya yaitu dengan memasukkan nilai $\alpha=1$, dengan $0 \leq \alpha \leq 1$. Dengan menggunakan $\alpha=1$, maka diperoleh matriks $\mathbf{G}$ dari $\mathbf{G}=\mathbf{U L}^{\boldsymbol{\alpha}}=\mathbf{U L}$ dan matriks $\mathbf{H}$ dari $\mathbf{H}=$ $\mathbf{L}^{1-\boldsymbol{a}} \mathbf{A}^{\mathrm{T}}=\mathbf{A}^{\mathrm{T}}$

4. Menghitung persentase kebaikan biplot

Menghitung persentase kebaikan biplot komponen utama dalam menjelaskan keragaman data yang dilakukan secara otomatis oleh aplikasi R-Shiny.

5. Membuat plot dari matriks $\mathbf{G}$ dan $\mathbf{H}$

Membuat plot dengan cara mengambil secara simultan dua kolom pertama dari masingmasing matriks $\mathbf{G}$ dan $\mathbf{H}$ menjadi matriks $\mathbf{G}_{2}$ dan $\mathbf{H}_{\mathbf{2}}$ sebagai titik-titik koordinat grafik dua dimensi.

6. Interpretasi plot

Interpretasi plot terbagi menjadi empat bagian, antara lain :

a Mencari kedekatan antar objek

Menghitung jarak jarak euclidian objek satu dengan objek lainnya untuk mencari kemiripan karakteristik antar objek. Semakin kecil jarak yang terhitung, maka semakin 
mirip karakteristik objek-objek tersebut. Sebaliknya, apabila semakin besar jarak euclidian, maka karakteristik antara kedua objek relatif berbeda.

b Keragaman variabel

Panjang garis vektor variabel menggambarkan variansi dari variabel penelitian. Semakin panjang garis vektor maka semakin besar variansi variabel tersebut. Semakin pendek garis vektor menggambarkan semakin kecil variansi variabel penelitian.

c Korelasi antar variabel

Menghitung korelasi antar variabel melalui sudut yang terbentuk dari dua buah garis vektor variabel melalui rumus :

$\operatorname{Cos} \theta=\frac{\left(h_{c 1} \times h_{d 1}\right)+\left(h_{c 2} \times h_{d 2}\right)}{\left(v_{c} \times v_{d}\right)}$

d Nilai suatu objek pada variabel

Menghitung hubungan variabel penelitian dengan objek yang diamati melalui nilai proyeksi variabel terhadap objek penelitian dengan rumus :

$$
\begin{aligned}
& \operatorname{Proy}_{\mathrm{ij}}=\frac{\left(g_{i 1} \times h_{j 1}\right)+\left(g_{i 2} \times h_{j 2}\right)}{\sqrt{g_{i 1}^{2}+g_{i 2}^{2}}}, \mathrm{i}=1,2, \ldots, \mathrm{n} ; \mathrm{j}=1,2, \ldots, \mathrm{p} \\
& \operatorname{Cos} \theta=\frac{\operatorname{Proy}_{i j}}{\sqrt{h_{j 1}^{2}+h_{j 2}^{2}}}
\end{aligned}
$$

Kemudian dari nilai $\operatorname{Cos} \theta$, dapat dicari besar sudut $\theta$. Sudut $\theta$ yang membentuk sudut lancip memberikan penjelasan bahwa variabel tersebut memberikan keunggulan pada objek penelitian. Sebaliknya, apabila sudut $\theta$ membentuk sudut tumpul akan memberikan penjelasan bahwa variabel tersebut memberikan nilai yang lemah pada objek penelitian.

\subsection{Perancangan Interface R-Shiny}

Tampilan aplikasi GUI R-Shiny untuk "Analisis Biplot Komponen Utama” ini terdiri dari empat bagian, meliputi header, sidebar panel, tab panel, dan main panel. Tab Panel terdiri dari 8 Tab, yaitu 8 tab, yaitu tab "Data", tab "Matriks transformasi", tab "Matriks SVD", tab "Masukkan nilai alfa", Tab "Kebaikan biplot", tab "Plot", tab "Interpretasi Plot", dan tab "Refferensi".

\subsection{Ilustrasi interface R-Shiny untuk analisis}

Interface ini digunakan untuk melakukan analisis biplot komponen utama dimana pengguna hanya perlu menginput file, mengetik nilai numerik, dan menekan tombol. Pada aplikasi analisi biplot komponen utama ini, hanya memerlukan beberapa proses. Pada menu "Data" digunakan untuk menampilkan data yang telah diunggah. Menu "Matriks Transformasi" digunakan untuk menampilkan hasil koreksi data awal terhadap rata-rata. Menu "SVD" digunakan untuk menampilkan matriks dekomposisi U, L, dan A. Menu "Masukkan Alfa" merupakan perintah untuk menginput nilai $\alpha$ yang ingin digunakan, dengan $0 \leq \alpha \leq 1$ kemudian menampilkan matriks G dan H. Menu "Kebaikan Biplot" digunakan untuk menampilkan nilai-nilai eigen dan kebaikan biplot $\left(\rho^{2}\right)$. Menu "Plot" akan memunculkan plot dari analisis biplot komponen utama. Menu "Interpretasi Plot" digunakan untuk melakukan interpretasi dari plot yang telah terbentuk. 


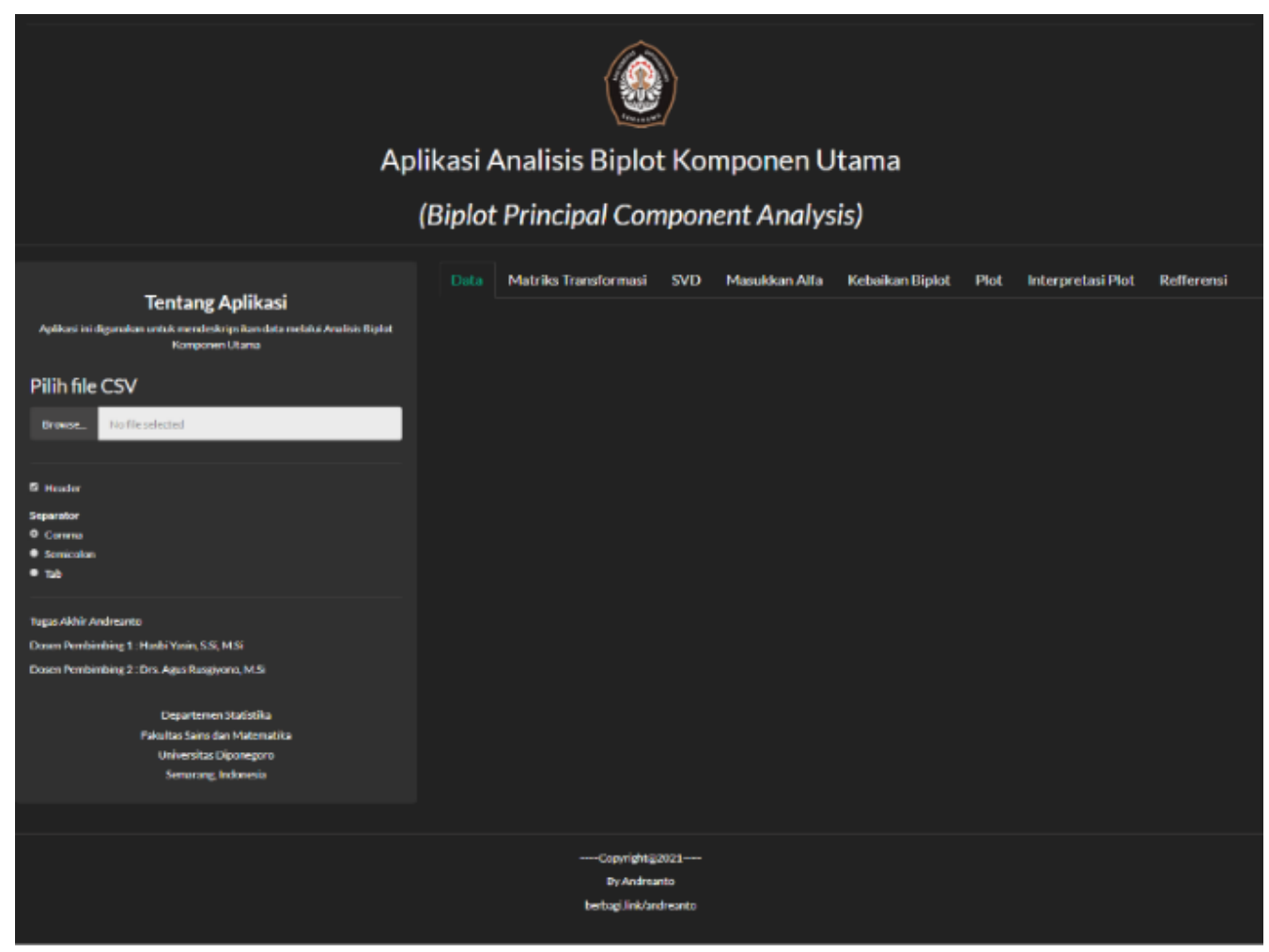

Gambar 2. Tampilan awal aplikasi Analisis Biplot Komponen Utama

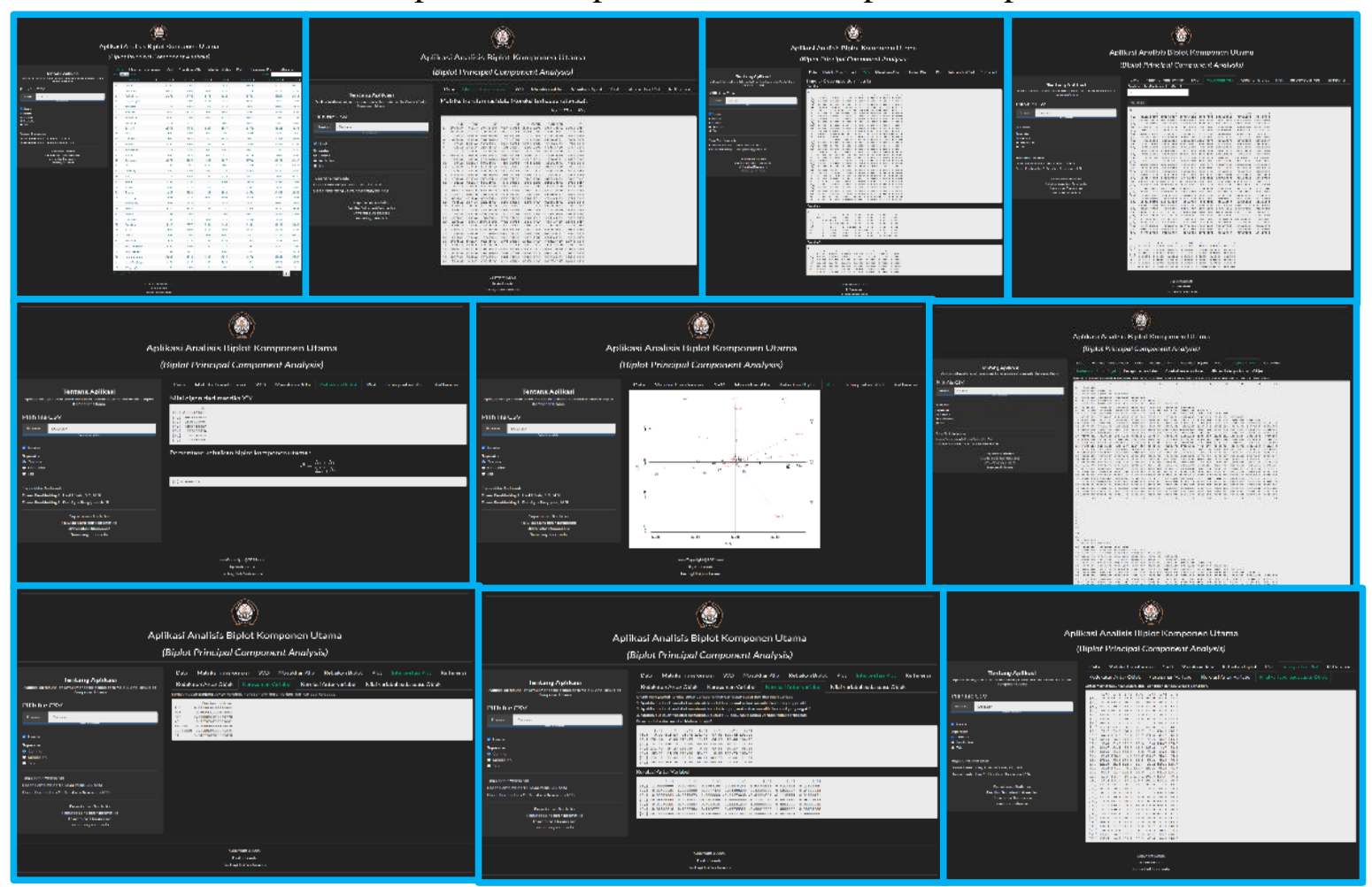

Gambar 3. Ilustrasi penggunaan Aplikasi Analisis Biplot Komponen Utama 


\subsection{Hasil Analisis Biplot Komponen Utama}

Aplikasi R-Shiny untuk analisis biplot komponen utama dapat memberikan luaran yang lengkap. Luaran ini dapat digunakan sebagai dasar dalam melakukan analisis biplot komponen utama. Berikut adalah hasil dari analisis biplot komponen utama dengan menggunakan nilai $\alpha=1$.

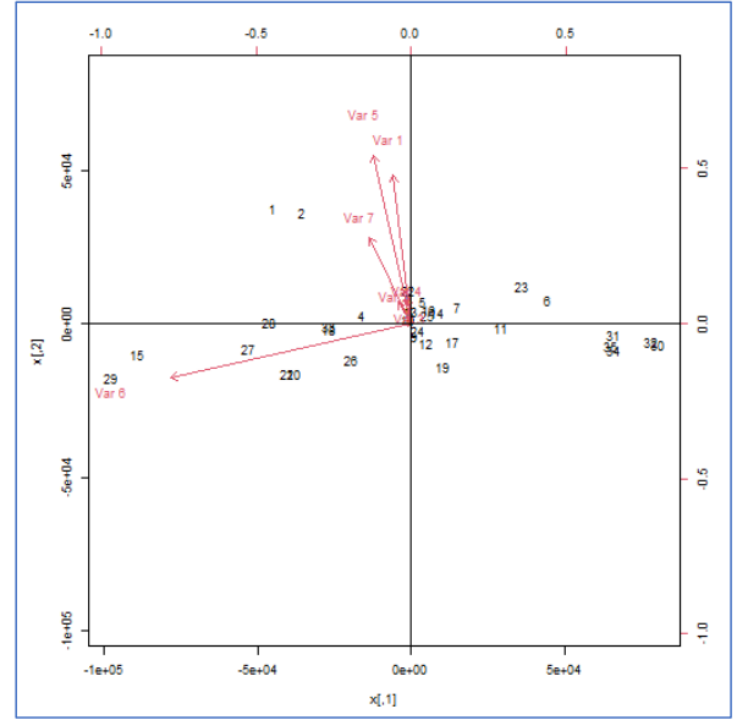

Gambar 3. Biplot komponen utama

Berdasarkan tampilan hasil dari aplikasi R-Shiny, persentase kebaikan biplot komponen utama dalam menjelaskan keragaman data terhadap pemilihan alat kontrasepsi yang digunakan oleh peserta aktif KB di setiap kabupaten/kota di Provinsi Jawa Tengah tahun 2019 adalah $\rho^{2}=0,9563253 \approx 95,63 \%$. Hal ini berarti bahwa interpretasi biplot komponen utama yang dihasilkan mampu menerangkan dengan baik data penggunaan alat kontrasepsi pada peserta aktif Keluarga Berencana (KB) di Provinsi Jawa Tengah tahun 2019.

Dalam interpretasi plot, kedekatan antar objek diinterpretasikan dalam bentuk matriks segitiga berukuran 35x35. Keragaman variabel diinterpretasikan dalam bentuk tabel. Korelasi antar variabel diinterpretasikan dalam dua matriks, yaitu matriks sudut yang terbentuk dari variabel-variabel dan matriks korelasi antar variabel. Nilai variabel pada suatu objek diinterpretasikan dalam bentuk matriks berukuran 35x7.

\section{KESIMPULAN}

Dari hasil dan pembahasan tentang aplikasi atau GUI R-Shiny yang digunakan untuk analisis biplot komponen utama pada contoh studi kasus penggunaan alat kontrasepsi pada peserta aktif KB di Provinsi Jawa Tengah tahun 2019 dapat ditarik kesimpulan bahwa aplikasi atau GUI R-Shiny yang telah dibuat memiliki banyak kelebihan, antara lain hasil lengkap yang meliputi tampilan data, transformasi data, penguraian matriks SVD, hingga grafik plot beserta interpretasi grafik plot. Kelebihan lain yaitu penggunaan yang mudah (user friendly) membuat pengguna tidak perlu menulis syntax seperti pada program R/Rstudio. Selain itu, tampilan dari aplikasi ini yang modern membuat pengguna nyaman dalam penggunannya.

Hasil dari analisis biplot komponen utama menggunakan aplikasi atau GUI R-Shiny dengan $\alpha=1$ memiliki persentase kebaikan biplot komponen utama yang baik, yaitu 95,63 $\%$. Hal ini menunjukkan bahwa interpretasi biplot komponen utama yang dihasilkan dapat menerangkan sangat baik hubungan antara kabupaten/kota dengan alat/metode kontrasepsi yang digunakan. 


\section{DAFTAR PUSTAKA}

Adhi, I. S. (2021, January 27). 11 Alat Kontrasepsi Beserta Kelebihan dan kekurangannya. Retrieved from Health Kompas: https://health.kompas.com/read/2020/06/07/060200168/11-jenis-kontrasepsi-besertakelebihan-dan-kekurangannya?page $=$ all

Gentle, J. E. (2007). Matrix Algebra : Theory, Computations, and Applications in Statistics. New York: Springer.

Jolliffe, I. (2002). Principal Component Analysis, Second Edition. New York: Springer.

Kong, X., \& Changhua Hu, d. Z. (2017). Principal Component Analysis Networks and Algorithms. Beijing: Science Press.

Mattjik, A. A., \& Sumertajaya, I. M. (2011). Sidik Peubah Ganda dengan Manggunakan SAS. Bogor: IPB PRESS.

Nugroho, S. (2008). Statistika Multivariat Terapan. Bengkulu: UNIB Press.

Purwandari, T., \& Hidayat, Y. (2016). Pengelompokan Kabupaten Dan Kota Di Jawa Barat Menggunakan Principal Component Analysis Biplot. Prosiding Seminar Nasional Pendidikan Matematika (pp. 3-6). Sumedang: Universitas Padjajaran.

Richard, A. J., \& Wichern, D. W. (2007). Applied Multivariate Statistical Analysis Sixth Edition. United States of America: Pearson Education, Inc.

Rifkhatussa'diyah, E. F. (2014). ANALISIS BIPLOT KOMPONEN UTAMA PADA BANK UMUM (COMMERCIAL BANK) YANG BEROPERASI DI JAWA TENGAH. Jurnal Gaussian, 3(1), 63.

Tirta, I. M. (2014). Pengembangan E-Modul Statistika Terintegrasi dan Dinamik dengan RShiny dan MathJax. Universitas Jember, 223-232.

Tirta, I. M. (2015). Panduan Pennyusunan Modul/Tutorial dan Analisis Data Online Berbasis Web Interaksi Menggunakan R-Shiny. Jember: Universitas Jember. 